\title{
Why Young Adult Speculative Fiction Matters
}

\section{Marek C. Oziewicz. 2015. Justice in Young Adult Speculative Fiction: A Cognitive Reading. New York: Routledge. 257 pp. ISBN: 978-1-138-80943-7}

DOI: 10.21066/carcl.libri.2018-07(01).0009

Although a lot of work has been done, both specifically and generally, on the topic of young adult speculative fiction, it is striking just how much of that work remains apologetic. Tarred doubly by the popular assumptions that "children's" books are simple and unchallenging, and that "fantasy" genres are frivolous or out of touch with reality, those who would study young adult speculative fiction often find themselves, with greater or lesser success, defending the relevance of their work. Marek C. Oziewicz's Justice in Young Adult Speculative Fiction falls at the successful end of this spectrum, laying out one of the most lucid explanations of why young adult speculative fiction matters that I have read in a long time. Drawing on a number of cognitive studies, Oziewicz argues that "human cognitive architecture is hardwired for a script-based narrative understanding" (5) and that literature supports the development of specific cognitive "scripts" relating to justice, with speculative fiction in particular offering opportunities for the evolution and alteration of such cognitive scripts (13). On the strength of this argument, Oziewicz makes the case for young adult speculative fiction as "one of the most important forges of justice consciousness for the globalized world of the $21^{\text {st }}$ century" (4).

Justice in Young Adult Speculative Fiction provides the first cognitive reading of young adult speculative fiction to focus specifically on justice. Both historical and cognitive in approach, it links the historical development of concepts of justice to the cognitive effects of narrative texts, arguing for a direct correlation between evolving forms of speculative fiction and evolving concepts of justice at both the personal and the societal level. As such, it provides a theoretical framework that is relevant not only to the fields of literature and cognitive studies, but also disciplines as wide ranging as law, politics, sociology, and education. In an increasingly multidisciplinary academic environment, this text offers insight into why young adult speculative fiction matters.

Oziewicz begins in Chapter 1 with an historical summary of the evolution of different concepts of justice, from old justice, to new justice, and finally to open justice, emphasising the way in which concepts of justice have expanded to be increasingly complex and inclusive over time. In this chapter Oziewicz also cements further the correlation between justice and literature, making the case for literature as an historical record of "soft facts" (34) pertaining to justice in which the evolution of concepts of justice can be traced and examined. Chapter 2 explores this correlation between justice and narrative more fully, providing a solid theoretical framework based on cognitive studies in a range of disciplines from neurology and sociology to narratology and literature.

Chapters 3 through 8 then provide specific readings of particular types of justice script: poetic justice (Chapter 3), retributive justice (Chapter 4), restorative justice (Chapter 5), environmental justice (Chapter 6), social justice (Chapter 7), and global justice (Chapter 8). Each section examines a range of different texts and sub-genres in young adult speculative fiction. Chapter 3, for example, examines poetic justice in a range of traditional fairy 
tales, from Perrault and the Brothers Grimm to Oscar Wilde and Hans Christian Andersen. Arguably one of the oldest forms of children's literature, these stories provide a logical starting point for a discussion of historical "old justice" concepts. Chapter 4, in contrast, shows how another "old justice" concept, retributive justice, is prevalent even in texts as modern as Philip Pullman's The Golden Compass or Nancy Farmer's The Islands of the Blessed. Chapters 6 through 8 then examine three particular manifestations of the "open justice" concept - environmental justice, social justice, and global justice - which are particularly relevant at the current moment in discourses about globalisation. From Isabel Allende's City of the Beasts to the film Monsters, Inc., these three chapters show the variety of ways in which representations of justice and the justice scripts available to young readers are opening up and becoming more complex. The wide variety of texts and time periods covered illustrates a key component of Oziewicz's argument, that although the broad concept of justice has evolved over time, no concept of justice has been completely erased or abandoned; as these chapters demonstrate, even very modern narratives retain traces of and commitment to older concepts of justice as well as newer, "open justice" interpretations.

One particularly significant theme that runs through many of the chapters in this volume is the distinction between theoretical concepts of justice, and the actual practice of law and government policy. As Oziewicz is at pains to point out, "there is [...] a difference between philosophical reflection about justice and the legal execution of justice" (24). He also points out, however, "[p]rotagonists in speculative fiction are always rebels, never the empire" (13). In fact, in much young adult speculative fiction, conflict overwhelmingly centres on the opposition of an individual to such established legal execution, making this disjunction between law and justice a focal point. Oziewicz's analyses expose and explore this disjunction, suggesting that it is crucial to the formation and development of justicerelated scripts. Furthermore, his comparison of the different developments in justice - from old to new to open justice - to the development of a plant stands in direct contrast, in fact, to the perspective often touted by law and policy makers of a society moving steadily away from barbarity and towards a universally enlightened concept of justice. As Oziewicz explores at length, young adult speculative fiction is particularly adept at exposing the untruth of this myth of human progress. Oziewicz's work, therefore, opens up interesting questions about the relationship between young adult fiction and the politics of youth and justice.

Justice in Young Adult Speculative Fiction, therefore, is an insightful critical intervention into discourses concerning the role of children's and young adult literature in an increasingly turbulent global justice climate. Neatly bridging the complexities of disciplines as wide ranging as neurology, narratology, sociology, education, literary studies, and cultural studies, this volume is truly interdisciplinary in its approach to young adult studies. It makes more than a superficial argument for the social relevance of children's literature, instead providing a solid theoretical framework with which to evaluate the effectiveness of young adult speculative fiction as more than merely frivolous entertainment. In Oziewicz's study, young adult speculative fiction is shown to be fundamental to our understanding of very real and very relevant social issues. 